analyser basert på væskestrømscytometri, enkeltcelle-PCR, multipleks-ELISA, enkeltcelleanalyser på tumorstamceller, enkeltcelleanalyser for å avdekke mikroheterogenitet og genom- og transskriptomanalyser på tumorceller enkeltvis.

Anselmetti og medarbeidere presenterer etter min mening en godt oppdatert oversikt over nye metoder og forskningsverktøy og gir eksempler. De ulike kapitlene gir fine oversikter over metoderepertoaret, men ikke så konkret informasjon at man vil kunne bruke dem som protokoll. Det gis dog gode referanser til originalartikler som beskriver metodene. En fare med denne typen utgivelse at den relativt raskt kan bli utdatert. Single cell analysis er imidlertid aktuell nå og burde være av interesse for forskere innen molekylærmedisin og andre som ønsker seg oversikt over nye metoder som nå i økende grad kommer til anvendelse etter hvert som behovet for molekylær forståelse på enkeltcellenivå øker.

\section{Vil telemedisinen redde verden?}

Wootton R, Patil NG, Scott RE et al, red

Telehealth in the developing world

318 s, tab, ill. London: RSM Press, 2009

Pris GBP 30

ISBN 978-1-85315-784-4

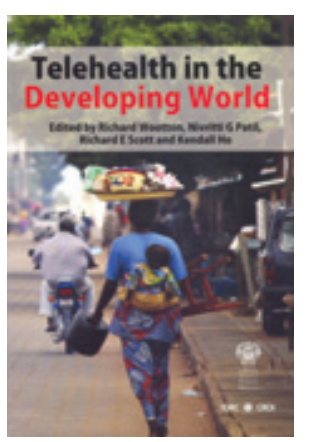

En turist i Afrika utvikler spesielle og sære symptomer ved hjemkomsten, og utkantlegen nord i Canada finner frem til en ekspert i sjeldne tropesykdommer ved Nelson Mandelauniversitetet i Durban. Det er ønskelig med en rask videokonferanse som kan bidra til å avklare diagnostikk og behandling. På begge steder finnes det nødvendige tekniske utstyret, så hva skulle hindre en slik løsning? Relevante helsemyndigheter begynner å stille spørsmål: Hvem er spesialisten i Durban og hvilke kvalifikasjoner har han/hun? Er vedkommendes kvalifikasjoner godkjent i Canada? Er dette tilfellet innenfor vedkommendes spesialitet? Vil vedkommende kreve salær? Vil dette åpne for en flom av liknende henvendelser? Siden det er behov for diagnostikk og behandling, vil vedkommende tropemedisiner være å anse som praktiserende i Canada? Hva med lisens? Hvem har det kliniske ansvaret? Hva med sykehusets og helseregionens rettslige ansvar? Kan det foreligge komplikasjoner av etisk karakter? Hva med konfidensialitet og privatlivets fred? Vil spesialisten ha behov for å se pasientens elektroniske journal for oppfølging av behandlingen eller ha behov for å gjøre egne opptegnelser etter videokonsultasjonen? I så fall, hva med sikkerhet, tilgang og autorisasjon, siden vedkommende ikke er ansatt ved foretaket?

Det sier seg vel selv at det til slutt ikke blir noen videokonferanse, men dette eksemplet hentet fra Telehealth in the developing world illustrerer godt de mange problemstillingene som må løses dersom begrepet global e-helse skal få praktisk betydning. Oppsummert er disse på helseinformatikksiden privatlivets fred, konfidensialitet og sikkerhet, inkludert pasientsikkerhet. For telehelse kommer i tillegg spørsmålet om lisensiering, rettslige forpliktelser og betalingsordninger.

Det er utvilsomt slik at telemedisin har potensial til å kunne bedre utnyttelsen av tilgjengelige helseresurser i u-land. Hovedutfordringene er imidlertid urealistiske forventninger, manglende langsiktig finansiering, manglende evaluering og mangelen på publiserte resultater og ekspertise.

Denne utgivelsen er den niende i en serie om telemedisinske emner. Målsettingen er å gi eksempler på vellykket implementering av konkrete prosjekter i utviklingsland innenfor administrasjon, utdanning og klinisk praksis. Målgruppen er uklar, men forfatterne håper at enhver vil finne noe av relevans. Den er rikt illustrert med fotografier og figurer, og i hvert kapittel er det referanser til videre lesing.

Eksemplene er å anse som vellykkede demonstrasjoner av bruk av telemedisin i u-land, men det må innrømmes at overbevisende dokumentasjon for kostnadseffektivitet ikke foreligger. Ressursfattige regjeringer gjør nok fortsatt best $\mathrm{i}$ å satse på ikke-virtuelle helsetjenester. Imidlertid er det verdt å legge merke til erfaringene fra Peru med et telemedisinsk nettverk basert på e-post via VHF-radiolink. I en studie har man nylig dokumentert at dette gir færre transporter av akuttpasienter fra helsesentre og helseposter.

Alt $\mathrm{i}$ alt er vel Telehealth in the developing world en bok av entusiaster skrevet for entusiaster. Verden går neppe fremover uten slike.

\section{Berit Olsen}

Institutt for samfunnsmedisin

Universitetet i Tromsø

\section{Knapt om immunologiske nevromuskulære sykdommer}

Pourmand $\mathrm{R}$, red. Immune-mediated neuromuscular diseases Frontiers of neurology and neuroscience. $170 \mathrm{~s}$, tab, ill. Basel: Karger, 2009. Pris CHF 198 ISBN 978-3-8055-9141-6

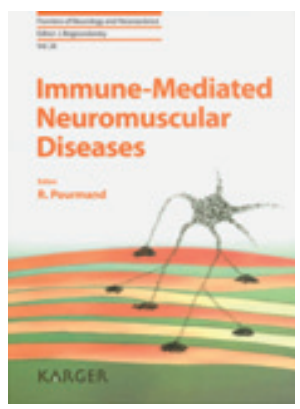

Denne relativt korte og lettleste boken gir gjennom ti kapitler en innføring i de vanligste og viktigste immunmedierte nevromuskulære sykdommene: akutte og kroniske nevropatier, vaskulitter, autoimmun autonom gangliopati, myastenia gravis og andre myastenier, myositter og autoimmunt stivhetssyndrom/stiff person syndome. Den er egnet som en innføring i disse sykdommene for spesialistkandidater i nevrologi og for andre leger som kommer borti pasienter med slike sykdommer. Teksten er imidlertid i mange tilfelle for knapp for lesere som virkelig ønsker å gå i dybden.

Med unntak av kapitlet om autoimmunt stivhetssyndrom, som er skrevet av to briter, er alle kapitlene skrevet av amerikanske nevrologer. Jeg stusser over at mange av forfatterne knapt har registrert artikler vedrørende emnene de skriver om i PubMed. Forfatterne er derfor i liten grad ledende internasjonale kapasiteter på sine respektive områder, hvilket man burde kunne forvente i en slik utgivelse. Dette er ikke minst viktig når det gjelder sjeldne tilstander der det ikke foreligger gode kliniske studier av alle aktuelle behandlingsmuligheter og forfatternes personlige erfaring og innsikt derfor er av særlig interesse. Jeg synes også redaktøren har vært litt for passiv i forhold til lengde og utforming av de ulike kapitlene. Det virker for eksempel litt underlig at det brukes nesten dobbelt så mye plass på en så sjelden tilstand som autoimmunt stivhetssyndrom som på de vanligere og svært viktige akutte nevropatiene.

I likhet med andre kapitler i Frontiers of neurology and neuroscience-serien er alle kapitlene i Immune-mediated neuromuscular diseases indeksert i PubMed. Mange medisinske biblioteker abonnerer på fulltekstversjonene av serien. Innholdet er derfor lettvint og gratis tilgjengelig for den som er tilkoblet et større medisinsk bibliotek. De fleste potensielle lesere trenger derfor ikke betale den relativt stive prisen på over 1000 kroner.

Trygve Holmøy

Nevrologisk avdeling

Oslo universitetssykehus, Ullevål 